\title{
ISOLASI DAN IDENTIFIKASI BAKTERI PENAMBAT NITROGEN UNTUK PEMBUATAN BIOFERTILIZER
}

\author{
${ }^{1}$ Asrul dan ${ }^{2}$ I Nyoman Pugeg Aryantha \\ ${ }^{1)}$ Politeknik Pertanian Negeri Kupang \\ ${ }^{2)}$ Insititut Teknologi Bandung \\ E-mail : asrulpoltani@gmail.com
}

\begin{abstract}
Nitrogen is a macro nutrient needed by plants. Generally, people use inorganic fertilizers to fulfill nitrogen nutrients in plants. The problem then is, the continuous use of synthetic nitrogen fertilizers has a direct negative impact on the soil and a derivative impact on human health. The use of microorganisms, in this case bacteria, to provide nitrogen to plants can be done by isolating it and making it a biological fertilizer agent. Nitrogen fixing bacteria was isolated on the land of the oil palm plantation of PT Astra Agro Lestari. The isolated nitrogen-fixing bacteria were then tested quantitatively for their ability to fix nitrogen. The bacteria with the highest nitrogen fixing ability were then identified by sequencing their DNA nucleotide bases so that the bacterial strains were identified. The result is that there are 13 bacteria that are able to fix nitrogen with the codes J1, J3, Q5, L1, L11, J31, D1, M6, M5, R1, P2, J4 and C7. The quantitative test shows that bacteria with code $\mathrm{D1}$ are the best at fixing nitrogen in the form of $\mathrm{NH} 4$, namely $0.27 \mathrm{ppm}$. The results of D1 bacterial DNA nucleotide base sequencing showed that the putitive Bacillus aerius strain $24 \mathrm{~K}$ with identical values and query cover reached $100 \%$.
\end{abstract}

Keywords: Bacteria, Nitrogen Fixer, Biofertilizer

\section{PENDAHULUAN}

Proses pertumbuhan tanaman tidak bisa terlepas dari ketersediaan unsur hara yang terdapat di tanah. Tanaman membutuhkan unsur hara mikro maupun makro dari media tumbuhnya. Jika kebutuhan tanaman terhadap unsur hara lebih 1000 ppm maka unsur tersebut dikatakan unsur hara makro dan jika kurang maka dikategorikan unsur hara mikro (Lakitan 2013). Tanaman membutuhkan unsur nitrogen bersama kalium dan magnesium dalam jumlah besar. Nitrogen diketahui berperan dalam proses sintesis protein dan proses biokimia yang terdapat di tubuh tumbuhan. Nitorgen berperan dalam proses pembentukan jaringan tanaman, fotosintesis, protein-asam amino dan sangat dibutuhkan saat tanamana memasuki vase vegetatif (Margaretha, 2015). Nitrogen berperan menyusun bobot kering protoplasma kurang lebih 50\% (Munawar, 2011).

Pemenuhan unsur hara nitrogen di dalam tanaman dapat diperoleh dari dua jalaur yaitu jalur organik dan anorganik. Jalur organik, nitrogen diperoleh dari 1). dekomposisi bahan organik dari tanaman atau hewan yang sudah mati dan 2) pemberian pupuk kandang. Pemenuhan nitrogen dari jalur organik dapat pula melalui pemanfaatan jasa mikroorganimse (bakteri) yang mempunyai kemampuan untuk memfiksasi nitrogen bebas. Jalur anorganik umumnya melipatkan pemakaian pupuk sintetik (kimiawi), yang umumnya lebih dikenal dengan pupuk urea. Masyarakat pada umumnya lebih mengandalkan pupuk anorganik nitrogen untuk diaplikasikan di lahan pertaniannya. Alasannya mudah pupuk anorganik lebih mudah didapatkan dan diaplikasikannya. 
Masalahnya kemudian, pemakaian pupuk nitrogen sintetik secara terus menerus memberikan dampak negatif secara langsung ke tanah dan dampak turunan ke kesehatan manusia. amine, calcium, alumnimun, boron dan cobalt, merupakan unsur pengikut yang terdapat di pupuk kimiawi yang bisa merugikan kesehatan manusia (Kumari,dkk 2014). Nitrogen oxides sebagai residu dari pupuk kimia nitrogen diketahui penyebab pemanasan global (Savci, 2012).

Pupuk hayati merupakan pupuk yang memanfaatkan kerja mikrorganisme (bakteri) untuk mensuplai unsur hara ke tanaman. Penelitian Widiyawati, dkk (2014) menunjukkan bahwa pupuk hayati penambat nitrogen mampu menggantikan pemakian pupuk kimia nitrogen di tanaman padi. Bakteri pengikat mitrogen dapat bersimbitiok maupun non simbiotik dengan tanaman. Rhizobium dan tanam legume contoh bakteri pengikat nitrogen yang bersimbiotik, sedangkan non simbiotik yaitu Bakteri dari genus Azospirillum (Steenhoudt \& Vanderleyden, 2000).

Nitrogen termasuk unsur kimia yang melimpah di udara. Masalahnya kemudian nitrogen yang melimpah tersebut, tidak bisa serta merta dimanfaatkan oleh tanaman. Bakteri pengikat nitrogen mampu mengubah nitrogen bebas menjadi mampu digunakan oleh tanaman dengan bantuan ezim nitrogenase. Enzim nitrogenase sendiri terdiri dari 2 kompleks enzim yaitu dinitrogenase dan dinitrogenase reduktase (Ludden, 2001). Melihat kemampuan bakteri dalam mengikat nitrogen maka perlu ada upaya untuk mengisolasi dan mengidentifikasi bakteri yang mampu memfiksasi nitrogen, yang kedepannya dapat digunnakan sebagai bulk pembuatan pupuk hayati yang menyediakan unsur hara nitrogen ke tanaman.

\section{METODE PENELITIAN}

Bakteri diperoleh dari sampling tanah rhizosper di daerah pangkalan Bun, tepatnya di area perkebunan kelapa sawit PT Astra Agro Lestari. Satu gram tanah rhizosper diencerkan dengan system pengenceran bertingkat sampai tingkat $10^{-5}$, menggunakan $\mathrm{NaCl}$ fisiologis. Pengenceran tingkat $10^{-5}$ dan $10^{-4}$ diambil 1 ml kemudian ditebar di cawan petri yang sudah berisi media nutrium agar (NA). Proses inkubasi untuk pertumbuhan berlangsung lebih kurang 24 jam, setelah itu bakteri yang tumbuh (murni koloninya) kemudian dipindahkan di agar miring.

Bakteri yang ada kemudian diuji kemampuannya untuk mengikat nitrogen dengan menggunakan media nitrogen free mineral yang ditambahkan brontomiul blue (BTB) dan $0,7 \%$ glukosa. Perubahan media dari biru menjadi kuning menandakan bahwa isolat itu mampu mengikat nitrogen (Yu, dkk 2011). Isolat yang terpilih kemudian dilakukan pewarnaan gram dengan system apusan kering. Tujuan pewarnaan gram bakteri untuk melihat morfologi bakteri dan golongan gram bakterinya, gram positif atau gram negatif. Sel bakteri yang berwarna ungu-kebiruan menandakan gram positif sedangkan merah menandakan gram negatif.

Bakteri selanjutnya diuji kemampunanya mengikat nitrogen secara kuantitatif dengan menumbuhkan bakteri di media pepton broth $(10 \mathrm{ml})$, maksimal tiga hari. Media pepton broth kemudian disentrifugasi dengan kecepatan 4.000 rpm kurung waktu 10 menit. Sekitar 1-2 tetes garam signette dan $0,5 \mathrm{ml}$ nessler ditambahkan di supernatan hasil sentrifugasi media pepton broth, kemudian di spektrofotometer dengan panjang gelombang 420 nm (Houda, dkk. 2014., Nurlita, dkk. 2001., Ahmad, dkk. 2008). Hasil absorbansi cahaya spektrofotometer di konversi menjadi ppm dengan menggunkan kurva standar $\mathrm{NH}_{4}$. Isolat bakteri yang paling bagus mengikat nitrogen secara kuantitaf kemudian diidentifkasi secara molekuler di Macrogen. Hasil data di macrogen kemudian 
Asrul \& I Nyoman Pugeg Aryantha, 2021. Isolasi Dan Identifikasi Bakteri Penambat Nitrogen Untuk Pembuatan Biofertilizer. Journal Viabel Pertanian. (2021), 15(1) 16-23

di Blast di National Center For Bioteknology Information (https://www.ncbi.nlm.nih.gov/) untuk mengetahui spesies isolatnya.

\section{HASIL DAN PEMBAHASAN}

Jumlah total isolat bakteri yang didapatkan dari tanah rhizosper perkebunan kelapa sawit PT Agro Lestari yaitu 103 isolat. Semua bakteri kemudian diuji kemampuannya mengikat nitrogen dengan di media media nitrogen bebas mineral + brontomiul blue (BTB) dan 0,7\% glukosa. Hasilnya menunjukaan ada 13 isolat bakteri yang mampu mengikat nitrogen. Tiga belas bakteri tersebut berturut turut dengan kode J1, J3, Q5, L1, L11, J31, D1, M6, M5, R1, P2, J4 dan C7. Indikator kemampuan bakteri tersebut pengikat nitrogen yaitu dilihat dari kemampuannya untuk mengubah warna media, dari biru menjadi kuning (gambar.1). Bakteri pengikat nitrogen mampu menseksresikan asam organik ke media tanpa ada unsur nitrogennya (NFFM) dan menyebabkan perubahan warna pada media (Yu.,2011).

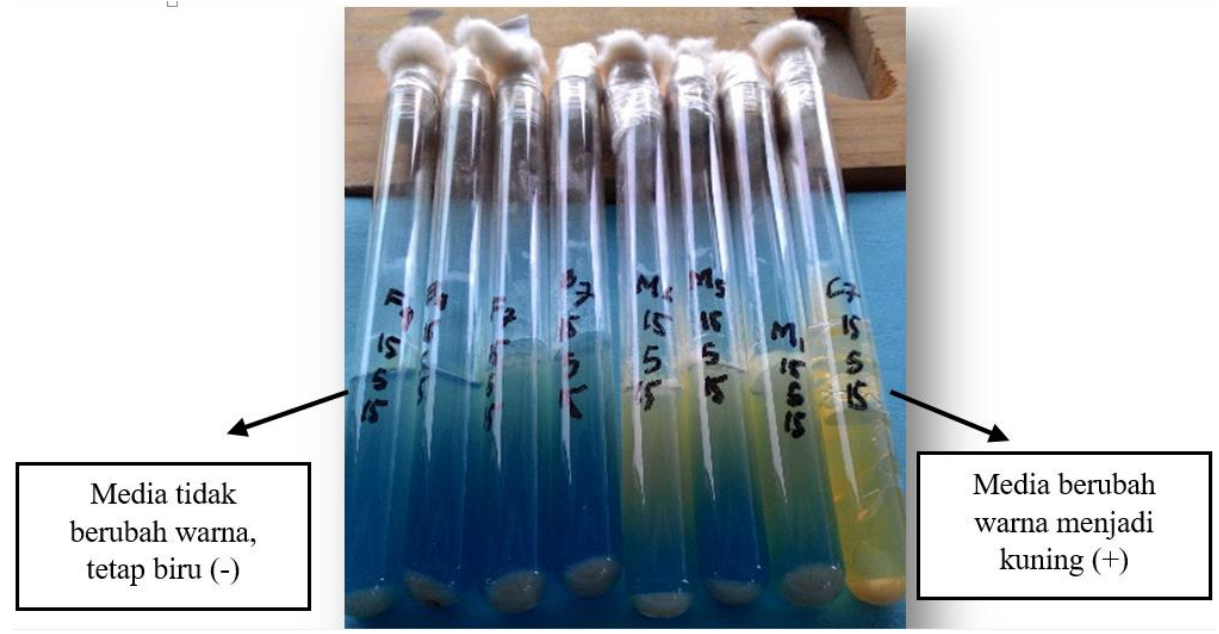

Gambar 1. Uji Kualitatif Bakteri Pengikat Nitrogen

\section{Morfologi dan Gram Bakteri}

Bakteri yang terpilih, (13 isolat), kemudian dikarakterisasi bentuk sel dan kecendrungan golongan gram bakterinya (positif atau negetif) dengan pewarnaan gram. Hasil morfologi bakterinya menunjukkan 5 basil pendek, 3 cocus, 4 basil panjang, dan 1 basil sedang, sedangkan kecendrungan golongan bakterinya yaitu 9 gram negatif (warna merah) dan 4 gram positif (warna biru-ungu). Adanya perbedaan warna ini disebabkan karena komposisi dan ketebalan dinding sel bakteri berbeda, sehingga reaksi pada pewarnaan gram pun ikut berbeda. Data distribusi pewarnaan gram 13 isolat tersebut dapat dilihat pada tabel 1 . 


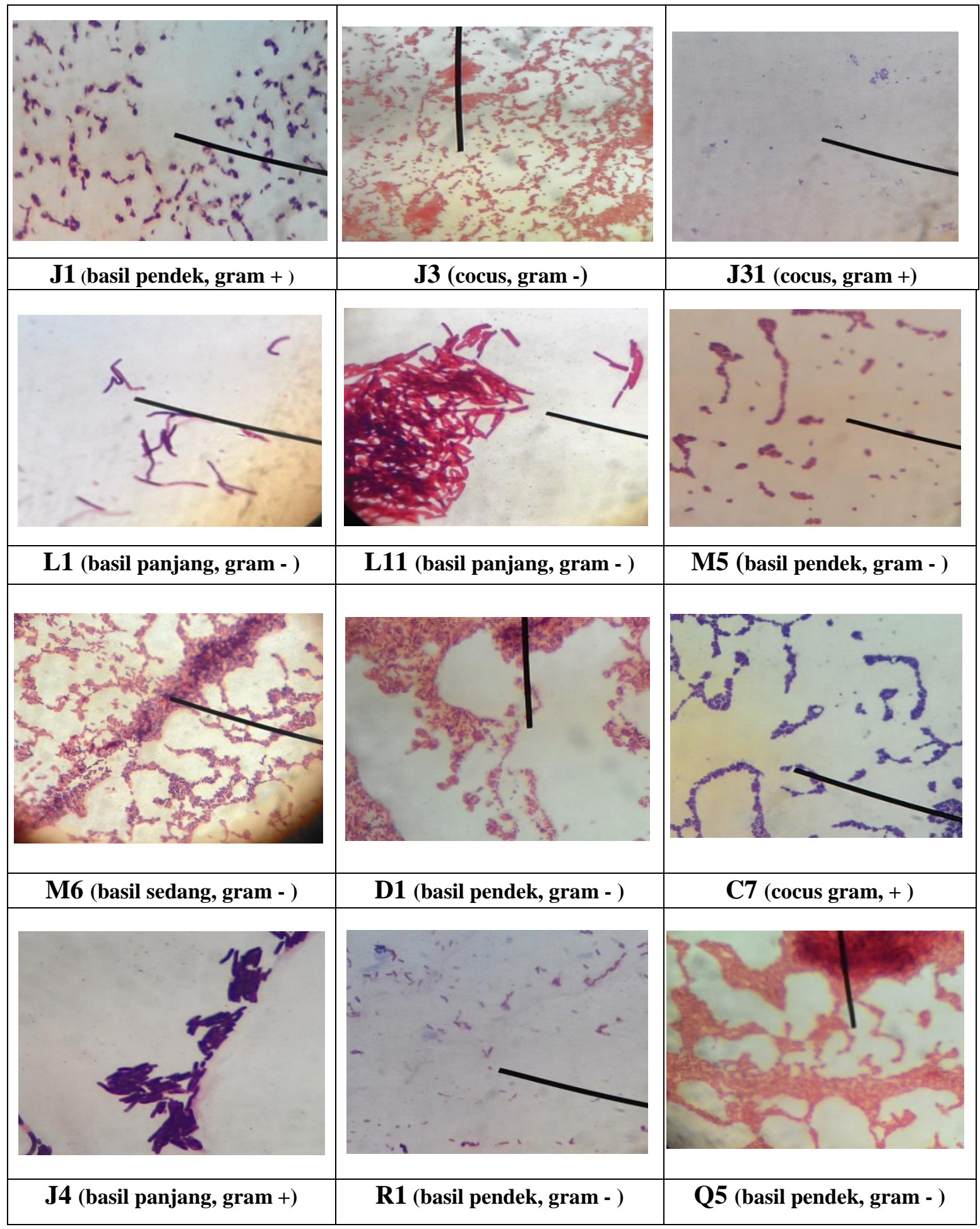




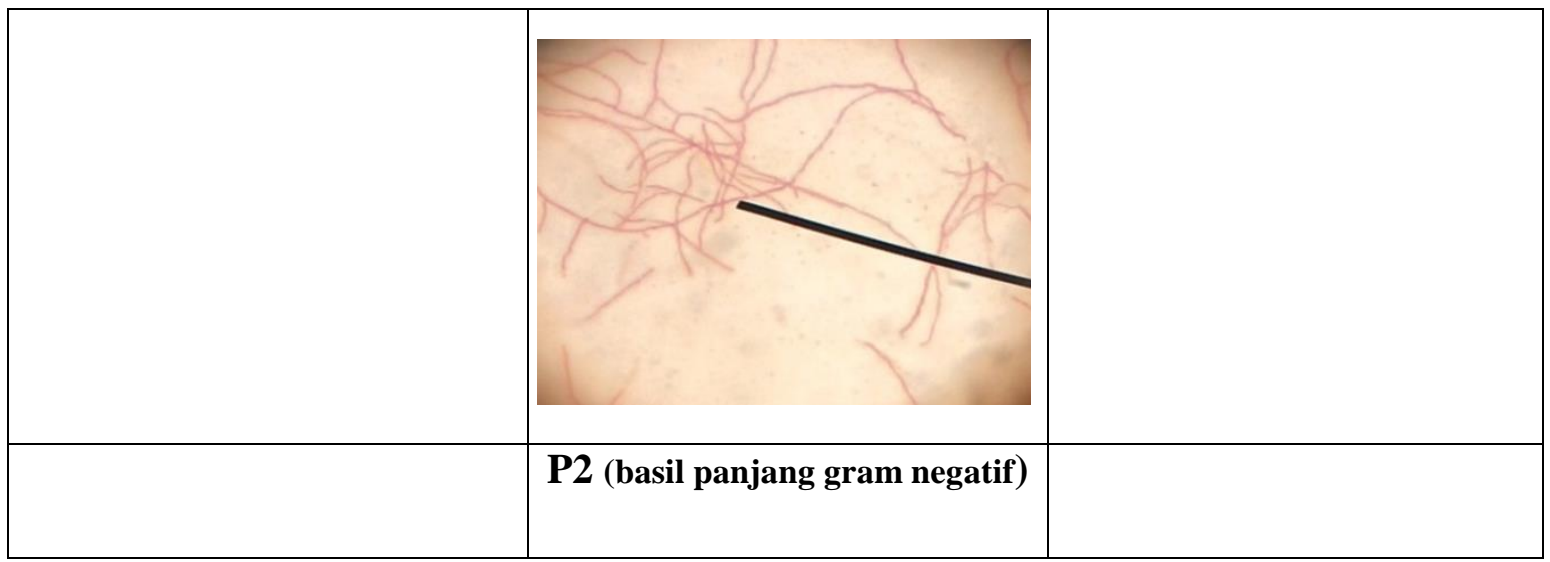

\section{Gambar 2. Morfologi Bakteri Pengikat Nitrogen}

Hasil tabel 1 menunjukkan bahwa, baik bakteri dari golongan gram positif maupun negatif mempunyai kemampuan untuk mengikat nitrogen. Tabel 1 juga menunjukkan bahwa 13 isolat bakteri tersebut umumnya mempunyai bentuk basil dan kokus. Ada 25 isolat bakteri pengikat nitrogen yang diisolasi dari dari tanah gambut hutan Trumaon Banda Aceh, yang umumnya berbentuk basil dan kokus (Lubis, dkk 2020). Penelitian Kaburuan dkk (2014) juga menunjukkan dari 31 isolat bakteri pengikat nitrogen, cuma ada 5 isolat yang berbentuk spiral selebihnya berbentuk basil dan kokus. Hal ini menandakan bahwa bakteri yang mempunyai kemampuan mengikat nitrogen umumnya berasal dari bakteri yang berbentuk basil dan kokus.

\section{Kuantitatif Pengikatan Nitrogen}

Hasil uji kuantitatif 13 bakteri pengikat nitrogen memperlihatkan bakteri D1 (tabel, 2) mempunyai kemampuan mengikat nitrogen paling tinggi sebanyak (0.27) ppm, diikuti J1 (0.24) ppm, J3 (0.23) ppm, M6 (0.23) ppm, J4 (0.23) ppm, Q5 (0.21) ppm, M5 (0.19) ppm, C7 (0.18) ppm, P (0.18) ppm, R1 (0.18) ppm, L11 (0.17) ppm, L1 (0.16) ppm dan J31 (0.12) ppm. Maksimalnya pengikatan nitrogen oleh bakteri D1 diduga karena sumber karbon dari media Pepton Broth yang menggunakan dektrosa (l-glukosa) sebagai sumber karbon cocok untuk mengoptimasi aktivitas maksimum enzim nitrogenase di bakteri D1

Bakteri mampu mengikat nitrogen karena adanya enzim nitrogense yang bekerja di bakteri tersebut (Ludden, 2001).. Penelitian Mirsha, dkk (1985) menunjukkan bahwa aktivitas maksimum enzim nitrogenase dari bakteri Nostoc linckia dengan menggunakan reduksi acytilen-etylen assay sangat dipengaruhi oleh jenis subtratnya. Tiga aktivitas maksimum nitrogenase ditemukan pada subtrat glukosa :78,5 \pm 5 , fruktosa : 74,3 \pm 6 , dan sukrosa :71,6 \pm 4.9 sedangkan 2 aktivitas minimum nitrogenase ditemukan pada sorbosa : $15,6 \pm 1.5$ dan ribose: 58,8 \pm 4.6 . (Mirsha, dkk 1985).

Hasil uji kuantitatif 12 bakteri pengikat nitrogen lainnya yang lebih rendah jika dibandingkan dengan di bakteri D1, mungkin dikarenakan sumber karbon dekstrosa (1glukosa) tidak cocok untuk mengaktivasi secara maksimum enzim nitrogenase di 12 bakteri tersebut. Perbedaan strain bakteri dan unsur karbon tentunya mempengaruhi aktivitas enzim nitrogenase yang terdapat di bakteri tersebut. Penelitian Young dan Torrey, (1986) memperlihatkan bahwa unsur karbon dari propionat mempunyai peran penting dalam pencapaian aktivitas maksimum enzim nitrogenase (pengikatan nitrogen) 
Asrul \& I Nyoman Pugeg Aryantha, 2021. Isolasi Dan Identifikasi Bakteri Penambat Nitrogen Untuk Pembuatan Biofertilizer. Journal Viabel Pertanian. (2021), 15(1) 16-23

di bakteri Frankia sedangkan aktivitas nitrogenase tidak terdeteksi jika sumber karbonnya diganti dengan glukosa, meskipun diberikan pelakuan yang sama dengan propionat.

Tabel 2. Hasil uji kuantitif bakteri pengikat nitrogen dalam ppm

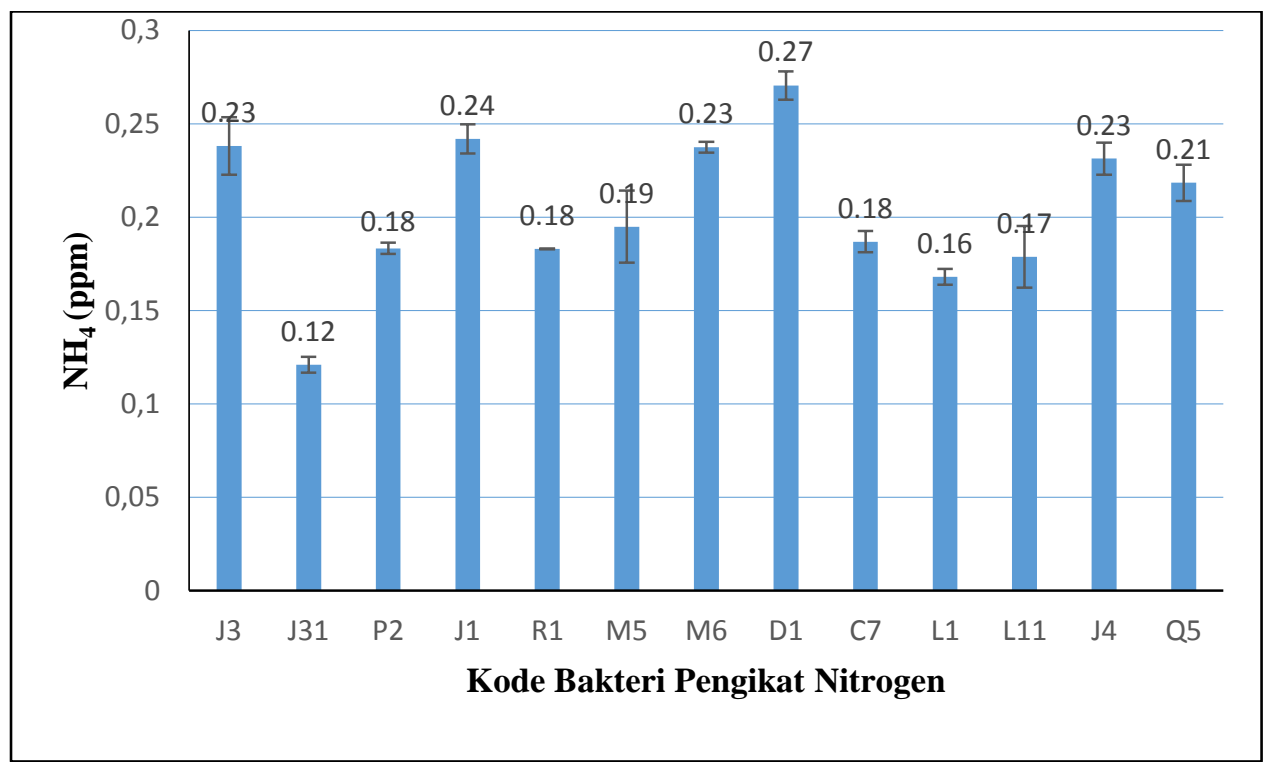

\section{Identifikasi Isolat Bakteri Pengikat Nitrogen (D1)}

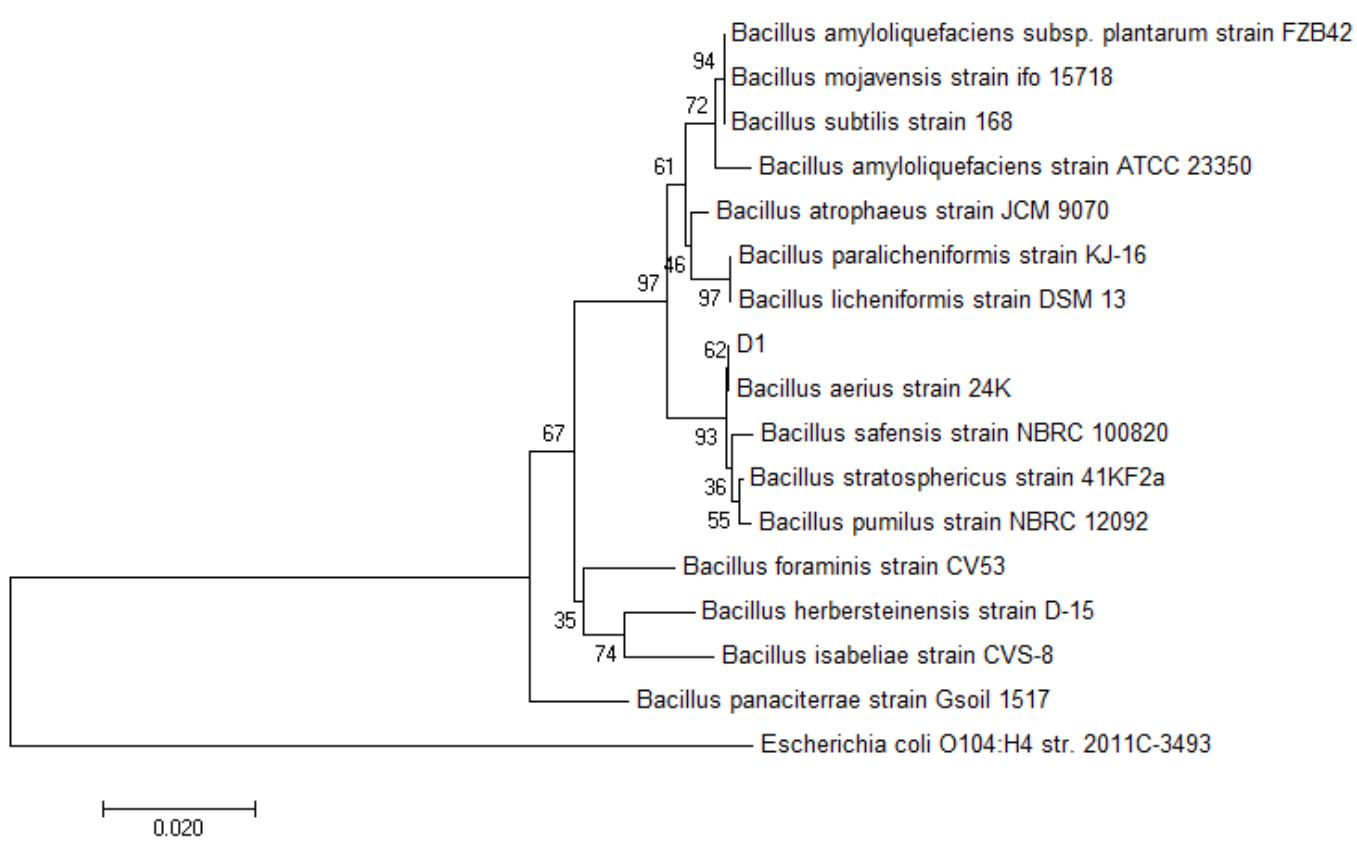

\section{Gambar 3. Kekerabatan Bakteri D1}

Hasil sekuensing bakteri D1 dengan menggunakan urutan basa nukleotida dari 16S rRNA-nya memperlihatkan bahwa bakteri D1 mempunyai nilai keidentikan dan query cover mencapai $100 \%$ dengan Bacillus aerius strain 24K. Terlihat di gambar 
kekerabatan bakteri D1 (gambar 3) menunjukkan bahwa Bacillus aerius strain 24K sangat dekat kekerabatannya dengan D1. Jadi dapat disimpulkan bahwa D1 adalah bakteri golongan Bacillus aerius. Penelitian Arora, dkk (2014) membuktikan bahwa Bacillus aerius termasuk golongan bakteri pengikat nitrogen dengan terlihat kemampuannya menghasilkan ammonium. Bakteri Bacillus termasuk golongan bakteri yang mampu mengikat nitrogen bersama bakteri Azetobacter dan Clostridium (Wagner, 2011).

\section{KESIMPULAN}

Ada 13 Bakteri yang mampu mengikat nitrogen yang diisolasi dari area perkebunan kelapa sawit PT Astra Agro Lestari. Bakteri pengikat nitrogen tersebar baik dari gram () dan gram (+). Bakteri D1 merupakan bakteri yang paling bagus mengikat nitrogen dan hasil identifikasi basa $16 \mathrm{~S}$ rRNAnya menunjukkan bahwa D1 adalah putative Bacillus aerius strain $24 \mathrm{~K}$.

\section{DAFTAR PUSTAKA}

Ahmad F, Ahmad, Iqbal, Khan MS (2008) Screening of free-living rhizospheric bacteria for their multiple plant growth promoting activities, Microbiological Research, 163, 173-181.

Arora S, Patel P N, Vanza MJ, Rao, GG (2014) Isolation and characterization of endophytic bacteria colonizing halophyte and other salt tolerant plant species from coastal gujarat, Afr. J. Microbial, Res, 8, 1779-1788.

Houda N, Hanene C, Ines M, Myriam BS, Imen D, Abdennaceur H (2014) Isolation and characterization of microbial communities from a constructed wetlands system: A case study in Tunisia, African Journal of Microbiology Research, 8, 529-538.

Kaburuan R, Hapsoh, Gusma W (2014) Isolasi dan Karakterisasi Bakteri Penambat nitrogen non-simbiotik tanah gambut cagar biosfer giam siak kecil-bukit batu, Jurnal agroteknologi, vol. 5 no. 1 , agustus $2014: 35$ - 39 .

Kumari KA, Kumar KNR, Rao CHN (2014) Adverse Effects of Chemical Fertilizers and Pesticides on Human Health and Environment, Journal of Chemical and Pharmaceutical Sciences (150-151).

Lakitan B (2013) Dasar-Dasar Fisiologi Tumbuhan, Depok, PT Rajagrafindo Persada.

Lubis SS, Sardi A, Huslina F, Lisa M (2020) Isolasi dan Karakterisasi Bakteri Pengikat Nitrogen Tanah Gambut Hutan Dari Kecamatan Trumon Aceh Selatan, Jurnal Pendidikan dan Biologi, 12(2), 117-129. doi: 10.25134/quagga.v12i2.2794.

Ludden PW (2001) Nitrogenase complex, Encyclopedia of life sciences, USA, 1-8.

Munawar A (2011) Kesuburan tanah dan Nutrisi tanaman. Bogor, IPB Press

Margaretha SL (2015) Dampak Inovasi Teknologi Pemupukan Nitrogen Pada Tanaman Jagung Terhadap Ketersediaan Pakan Ditingkat Petani (Studi Kasus: Kabupaten Gowa), Diakses di http://balitsereal.litbang.pertanian.go.id/wpcontent/uploads/2018/01 /15se87.pdf.

Mirsha DK, Kumar, HD, Jha M (1985) Effects of Some Carbon Sources on Growth and Nitrogen Fixation in the Cyanobacterium Nostoc linckia, Biologia Plantarum (Praha), 27, 1-5. 
Nurlita H, Utomo S (2011) Potensi nitrifikasi oleh bakteri yang terdapat di laut aliran kali plumbon, laut aliran kali banjir kanal barat dan laut aliran kali banjir kanal timur. Jurnal Presipitasi, 8, 1-7.

Savci S (2012) An Agricultural Pollutant: Chemical Fertilizer. International Journal of Environmental Science and Development, Vol. 3, No. 1.

Steenhoudt O, Vanderleyden J (2000) Azospirillum, a free-living nitrogen-fixing bacterium closely associated with grasses: genetic, biochemical and ecological aspects, FEMS Microbiology Reviews 24, 487-506.

Wagner SC (2011) Biological Nitrogen Fixation. Nature Education Knowledge 3(10):15

Widiyawati I, Sugiyanta, Juneadi A, Widyastuti R (2014) Peran Bakteri Penambat Nitrogen untuk Mengurangi Dosis Pupuk Nitrogen Anorganik pada Padi Sawah. J.Agraon. Indonesia 42 (2) : 96-102.

Young P, Torrey JG (1986) A comparison of carbon source utilization for growth and nitrogenase activity in two Frankia isolates, CaN. J. Microbial, 32, 353-358.

Yu, SS, Latt ZK, Kyew EP, Lynn, TM (2011) Accumulation of ammonia in culture broth by wild-type nitrogen-fixing bacterium, Stenotrophomonas maltophilia., IJABPT, 2, 72-77. 